\title{
FROM PHENOMENA TO IMPLEMENTATION: LESSONS AND CHALLENGES OF ADMINISTRATIVE REFORMS IN INDONESIA
}

\author{
Oscar Radyan Danar \\ Senior Lecturer, Department of Public Administration, \\ Faculty of Administrative Science, Universitas Brawijaya, Indonesia. \\ Address: Jl. MT. Haryono No.163, Ketawanggede, \\ Lowokwaru, Kota Malang, Jawa Timur 65145, Indonesia \\ E-mail: oscar@ub.ac.id
}

\section{Bevaola Kusumasari}

Senior Lecturer, Department of Public Policy and Management, Faculty of Political and Social Sciences, Universitas Gadjah Mada, Indonesia Address: Jalan Socio Yusticia No. 1, Bulaksumur, Yogyakarta 55281, Indonesia E-mail: bevaola@ugm.ac.id (corresponding author)

\section{M.R. Khairul Muluk}

Associate Professor, Department of Public Administration, Faculty of Administrative Science, Universitas Brawijaya, Indonesia Address: Jl. MT. Haryono No.163, Ketawanggede, Lowokwaru, Kota Malang, Jawa Timur 65145, Indonesia E-mail: mrkhairulmuluk@ub.ac.id

\begin{abstract}
Administrative reform has been recognized as one of the most prominent activities of governments intending to keep up with the recent trends of dynamic societies around the world. In recent years, the discussion in the reform literature has attracted significant attention from public administration scholars. It includes various methods and discusses a series of experiences of the reform movement around the world within multiple political landscapes, economic settings, and international turbulences. This paper presents the experience of administrative reform in Indonesia as one of the developing countries in Southeast Asia with a complex history of a colonial legacy. This study analyzes the prominent works of literature discussing the reform experience in Indonesia combined with theoretical perspectives of administrative reform. It highlights three major findings; first, the phenomenon of administrative reform in Indonesia was moving against the reform trend of most other developing countries; second, institutional arrangements play a critical role in repairing the reform trajectory; and third, the current progress of administrative reform in Indonesia still indicates the minimum achievement in some institutions. The discussion of this study, bordered by the settled time frame of reform implementation in Indonesia, is comprised of past and current experiences as well as the future projection of Indonesia administrative reform.
\end{abstract}


Keywords: administrative reform; public administration; Indonesia.

Citation: Oscar Radyan Danar, Bevaola Kusumasari \& M.R. Khairul Muluk (2020). From Phenomena to Implementation: Lessons and Challenges of Administrative Reforms in Indonesia. Public Administration Issues, No 6 (Special Issue II) pp. 33-50 (in English), DOI: 10.17323/1999-5431-2020-0-6-33-50.

\section{Introduction}

It has been more than a half century since overwhelming discussion between continental and Anglo-Saxon policy adorned the literature of Scandinavian public administration behavior (Jorgensen, 2006). Reverting to the historical view, both of these notions are fundamentally different in terms of philosophical perspective as well as contextual approaches (Ooghe \& Langhe, 2002). At least for many of the continental models with a strong orientation toward formal policy attributes such as (Kuhlmann, 2015; Warin, 2005). The AngloSaxon trends which have been motorized by American values promote business type management cultivated on a new public management perspective (Benouareth \& Gacem, 2019). Modern states have always had a reform agenda for enhancing the efficiency of the public sector. This has seen governments worldwide experiment with a wide variety of changes under evolving theories and models of public management. The dominant New Public Management (NPM) model was dictated and shaped in the 1980s and 1990s. The growing role of market forces in privatizing and outsourcing services was one of the most important developments during this period of cooperation agreements between the private and public sectors (Siddiquee \& Xavier, 2020). However, NPM has not provided cost-effective services and performance for more than 20 decades (Kisner \& Vigoda-Gadot, 2017). It is also accused of causing more issues, including public service fragmentation and the deterioration of public values (Schick, 2002). In contrast, the continental movement prefers its European style of legal-based management (Breuker, Valente \& Winkels, 2005). Although both Anglo-Saxon and continental supporters were fundamentally different in their perspectives, they do agree that the social system will continuously change over time. One piece of prominent evidence supporting this statement was when the UK Prime Minister, Tony Blair, at his speech in the European Parliament on June $23^{\text {rd }} 2005$, was opposing the 'pure' continental model and emphasizing the need to inject the Anglo-Saxon spirit into Europe. He then, in his words, proposes the need to adjust the old policy configuration with the recent trends of the social system (Warin, 2005).

The change of social system will bring in new social trends and shift the old ones into the records (Haferkamp \& Smelser, 1992). It carries new human behavior, outlook, thought, and other innovative spirits. These demand a new managerial model, planted in a new form of governance which is called administrative reform (Ocampo, 2002). The fact is that administrative reform is necessary for all kinds of government patterns, even for the policies of continental countries with their strong obedient behavior toward formal policy attributes. Roughly five dec- 
ades after it had been introduced in Europe in the late 1970s, the supporters of administrative reform were increasing, together with the growth of market forces (Farazmand, 2002). The spirit of liberalization was continuously pushing governments and their existing mechanisms, demanding reorganization, deregulation, privatization and other bureaucratic adjustments (Nikos, 2001).

Administrative reform in European countries was highly related to market orientation beyond its context of ideology and political regimes (Farazmand, 2002). This condition is slightly different compared with the administrative reform occurring in other countries outside continental European, especially for the reform's case in developing countries, which always emanate valuable experiences. In addition to this fact, perhaps the administrative reform in many Asian countries is the best case to illustrate the condition. Numerous of them are still labelled as third world countries indicating the weak to moderate performance of their governments in attaining their society's welfare.

There are at least two underlined justifications as to why the study of administrative reform in developing countries always provides valuable discussion. First, the governments in developing countries face multi-dimensional problems as many of them have limited control over the economic, social, and political environment (Cheung, 2005). There are plenty of empirical studies indicating the significant contribution of those external environments toward the success of policy implementation (Sarker, 2006; Ohemeng, 2010; Anggriawan, 2016; Strehlenert, 2017; Guga, 2018). Therefore, the policymakers will frequently face strong turbulence when they fail to maintain those external environments. In this case the action taken by them, especially on reform, is vulnerable toward the possibility of policy failure.

A few steps further apart from this discussion, there are internal matters of government in developing countries which commonly become a particular barrier to controlling the stability of those external environments. It is notoriously known that the problem of capacity or institutional capacity is still the major reason for the ills of many administrations in developing countries. Under this circumstance, the governments in developing countries are bound by two major tasks for their administrative reform. On the one hand, they should ensure the external environment to support the reformation's pace, but on the other hand they have to deal with complex internal problems within their base. Second, most developing nations are facing a cultural conflict between their fundamental culture and their significant dependency on their colonial legacy (Farazmand, 2002). It has been widely recognized that the historical experience of these nations in the past might also influence the culture of government such as administrative traditions, imperial legacies or political philosophy (Cheung, 2005). This historical experience can involve multiple timeframes, periods, regimes and the colonization era is no exception. Accordingly, there are two major possibilities for developing countries when dealing with administrative reform. The cultural conflict can be a barrier impeding the reform process, or it can provide valuable experience from the past to be a reference for a better future.

This study intended to reveal the phenomenon of administrative reform in one developing country in Asia called Indonesia. It is aimed to seek information 
regarding the progress and challenges of the Indonesian government in delivering the administrative reform from its early starting point (1998) until the recent updates in 2019. It examines selected information through the review toward the recent and relevant literature published by official government institutions, academic, and non-governmental organizations. Indonesia was selected as the case study due to its compatibility with both of the above justifications. In addition, it has undergone reformation for more than two decades, which is expected to provide a series of interesting discussions in the relevant format.

\section{Context and Mechanism of Administrative Reforms in Developing Countries}

It has become a common fact that the world has recently passed many transformative ages of social sciences. The rise of power of the intellectual class has meant a permanent revolution of modernization with the dynamic spirit of society (Fisher, Miller \& Sidney, 2007). This scenario has consequently demanded governments as rulers to adjust their mechanisms in order to take onboard recent developments (Farazmand, 2004). In line with an increasing number of demands from a dynamic society for efficient services of government, administrative reform has been chosen as the primary option to improve administrative machineries (Pollitt \& Bouckaert, 2004). However, in a broader context, there are always frequent questions aligning the implementation of administrative reform as the government's choice to deal with complex problems of society, such as "will the reform truly solve the problem? (Khemani, 2017)" or "what kind of reform ought to be undertaken by the government to put themselves in a proper condition?" (Cope, 1997) or "how far does the government need to change?" (Demir \& Aktan, 2016).

Whether acknowledged or not, many public officials would agree that reform decisions are quite challenging. At least, it is relevant to illustrate the administrative reform in France in the early nineteenth century with its enlightenment toward the role of administrator (Wagner, 2001); in Britain when it came together with Victorian England (Meer, 2009); or in the United States at the establishment of reform centered institutions (Volger, 2018). Besides this evidence, the situation of reform in developing countries might tell various stories. While a researcher may put much attention into observing a success story of reform experienced in a developed country, at the same time there are many components that need to be considered to rebuild those success stories when it is going to be applied in developing countries. Different kinds of political landscapes, governing experiences, administrative cultures or organizational capacities would become important attributes that need to be considered (Farazmand, 1999a).

The context of administrative reform in developing countries has commonly commenced its discussion by presenting the current development of the administration itself. Farazmand (2002) conveys that the development of administration in less developed countries suffered from chronic ailments of dependency, instability, and policy confusion. The dependency of developing countries has been frequently caused by economic and human development motives to the 
developed nations and international organization (Roy, 2016). Under this circumstance, the economic situations in developing countries are vulnerable toward the influence of higher developed countries, for example when financial contagion and capital fighting had put many southeast Asian countries into economic crisis in 1997 (Allen \& Gale, 2002; Jeon, 2012) or when the problem in the US capital market in 2007 had generated more than 7.7 million unemployed in Brazil (Proni, 2012).

In a more detailed look, the economic condition in less developed countries is strongly associated with political stability. The huge burden of crisis may create a devastating impact, such as the downfall of Suharto's regime in Indonesia in 1998 (Thoha, 2000; Maggy et al., 2011). Apart from both economic dependency and political instability, policy confusion has often become another obstacle for developing countries to succeed in their reform. Farazmand (2002) agreed that meeting these challenges is a formidable task for leaders in developing nations. These are substantial matters then covering the context of administrative reform in developing countries, and which are difficult to be separated from political, economic, and administrative components ${ }^{1}$ (Caiden, 1991). In most cases, the administrative reform in developing countries was conducted as a spontaneous response to critical situations rather than the anticipation of needs (OECD, 2001). Consequently, many of those are frequently walking into unforeseeable developments without a clear vision, settled constituency, planned programs or supported stakeholders.

A theoretical classification of administrative reform has been offered by Peters (1994) defining the early starting point of administrative reform comprised of a purposive (top-down), environmental (bottom-up), and institutional model. The identification of the model as presented in Table 1 is useful for understanding the motive of administrative reform undertaken by the government.

Table 1

\section{Early starting point of administrative reform}

\begin{tabular}{|l|l|}
\hline \multicolumn{1}{|c|}{ Classification } & \multicolumn{1}{c|}{ Shaping factors } \\
\hline Purposive (top-down) & $\begin{array}{l}\text { - Political will of certain actors, elites or powerful individuals } \\
\text { (Farazmand, 2002); }\end{array}$ \\
& - Need for political elites (Chester \& Wilson, 1984; Caiden, 1970); \\
& - Political - Administrative reason (Peters, 1994) \\
\hline Environmental (bottom-up) & $\begin{array}{l}\text { - Environmental conditions including economic, social or cultural } \\
\text { (Farazmand, 2002); } \\
\end{array}$ \\
\hline Institutional & - Administrative reaction toward the current change and trends \\
\hline & $\begin{array}{l}\text { (Killian \& Eklund, 2008) } \\
\text { (Farazmand, 2002) }\end{array}$ \\
\hline
\end{tabular}

Source: Peters (1994); Farazmand (2002); Killian \& Ekund (2008) - modified

\footnotetext{
1 The administrative components this section refers to asymmetric rule and regulation generated from the consequence of policy confusion which is often impeding the reform process.
} 
In order to examine the impact of early starting points as the trigger for administrative reform in developing countries, perhaps the reform experience from China, Japan, and South Korea will illustrate a comparable perspective. These countries have undergone long experiences of administrative reform and recently transformed into developed countries. Therefore, they have been recognized as the benchmark of administrative reform in many Asian developing countries. In China, the trigger of administrative reform denotes the government agenda under Deng Xiaoping's regime between 1978 to 1989 (Naughton, 2009). Similarly, in South Korea the reform was also initiated by the strong political will of president Roh Tae-Woo in 1988 resulting in a dominant topdown reform movement. In Japan, however, the situation is slightly different, i.e., when the culture of 'kaizen' blended with the leader's political will it results in the collective value which is applicable for better administrative reform.

\section{Trajectory and Trend of Administrative Reforms}

Most administrative reforms have occurred through internal initiatives leading to top-down reforms or by strong pressure from outside which triggered the bottom up movement (Fullan, 1994). Whether it has occurred by top-down or bottom up mechanism, both of these factors will definitely carry the spirit of change and adapt toward the new conditions (Killian \& Eklund, 2008). In line with this circumstance, the need for completing the reform scenario is important. Most administrative reform cases have successfully changed the government system, but not all of them were able to move into the desired goals. In some developing countries, the effort of reform can easily lead the nation into reform failure (Caiden, 1991). In other cases, the reform movement has been too tired to achieve the desired goals with tough resistance from the status quo resulting in an undesired movement into biased direction (Prasojo, 2012). It generates a condition called reform fatigue, when the reform is neither reaching the desired outcome nor falling back to the status quo (OECD, 2001). Some experiences of reform fatigue can be illustrated as prominent examples, such as in Australia (Banks, 2005), in the Netherlands (Vries, 2016), and in some Latin American countries (Ortiz, 2003). Although sometimes the government has said that the reform fatigue is slightly better than reform failure. However, for clear measurement, each of these examples failed to meet the desired goal of the reform.

In fact, both reform fatigue and reform failure are avoidable if the government maintains the administrative reform with a good reform scenario that is adaptive to the trend and propelled with a clear trajectory (Pollitt \& Bouckaert, 2017). The existence of a trajectory in administrative reform will constantly guide them from an early starting point onto the desired direction (Pollitt \& Bouckaert, 2004). However, setting the reform trajectory itself is not as simple as written in a conceptual paper. One of the major reasons explaining this is the fact that the government is not a single entity (Killian \& Eklund, 2008). Needless to say, the administrative reform trajectory often resulted 
from a series of complicated discussions between politicians and bureaucrats (Vries, 2016).

The phenomenon of administrative reform shares a single space for both politicians and bureaucrats; this has become a common fact, even it is separated from the context of political reform itself $^{2}$ (Bidhya \& Ora, 2014). In most detailed experiences, the administration will be closer to the bureaucrat's sphere but it is almost impossible to neglect if the reform agenda is also part of a political decision. Under this circumstance, the theory of bureaucratic-politics has been considered as one of the most important tools for understanding the decision-making process (Bidya \& Ora, 2014). It covers some specific attributes of reform such as relations, dispositions, interests, and values that are relevant in identifying the reform trends. The following (Table 2) illustrates the current prominent trend in administrative reform in developing countries over the last five decades.

Table 2

\section{Current prominent trends in administrative reform}

\begin{tabular}{|c|c|c|c|}
\hline Year & Popular trend & External supporters & Administrative reform areas \\
\hline $1950 s$ & $\begin{array}{l}\text { Post-war } \\
\text { Orientation }\end{array}$ & $\begin{array}{l}\text { Western and } \\
\text { capitalism power }\end{array}$ & $\begin{array}{l}\text { - Capacity building that serves the political ends } \\
\text { of anti-communist and anti-Soviet; } \\
\text { - Extensive development of security and police } \\
\text { forces; } \\
\text { - Managerial training for capitalist development; } \\
\text { - Bureaucratization for political control }\end{array}$ \\
\hline $1960 s$ & $\begin{array}{l}\text { Institution } \\
\text { building }\end{array}$ & Western influence & $\begin{array}{l}\text { - Provided a major impetus for bureaucratizing } \\
\text { societies in less developed nations under Western } \\
\text { influence; } \\
\text { - Bureaucratization, as part of agrarian } \\
\text { reforms, prevented a peasant-based revolution } \\
\text { by establishing state control over both rural } \\
\text { and urban areas }\end{array}$ \\
\hline $1970 \mathrm{~s}$ & Nationalization & $\begin{array}{l}\text { International } \\
\text { pressure }\end{array}$ & $\begin{array}{l}\text { - Any kind of reorganizations within public } \\
\text { sector to create society's welfare }\end{array}$ \\
\hline 1980 s & $\begin{array}{l}\text { The opposite } \\
\text { direction }\end{array}$ & $\begin{array}{l}\text { Global corporations } \\
\text { \& International } \\
\text { organizations }\end{array}$ & $\begin{array}{l}\text { - De-bureaucratization replacing the earlier } \\
\text { trends of institutional building }\end{array}$ \\
\hline 1990s & $\begin{array}{l}\text { Market-based } \\
\text { philosophy }\end{array}$ & $\begin{array}{l}\text { Marketization and } \\
\text { privatization has } \\
\text { created chaos }\end{array}$ & $\begin{array}{l}\text { - Public administration has transformed into } \\
\text { Administration for public for social control; } \\
\text { - Expansion the role of military, security, } \\
\text { and police. }\end{array}$ \\
\hline
\end{tabular}

Source: Farazmand 2002 (modified).

\footnotetext{
2 The fact that administrative reform is often involving political interference, while the political reform lies in a different dimension which is not always pulling the participation from bureaucrats.
} 


\section{A Brief Chronology of Administrative Reform in Indonesia}

It is almost impossible to separate the discussion of administrative reform in Indonesia beyond the context of economic and political perspective, since all of these have direct correlation. It began in 1997 with the huge financial crisis hampering the economic stability and generating instant poverty in many Asian nations.

In Indonesia the impact of this crisis resulted in the untrustworthiness of the national government which has reigned for more than three decades along with Suharto's tenure (1967-1998). The crisis has also awakened the awareness of society about the importance of injecting democratic values into the government. However, the existing administrative culture in Indonesia at that time was too rigid to accommodate the changes.

The administrative culture of Indonesia, which was fully granted through the highest constitution in 1945 (before its amendment), placed the president in an absolute position as the head of the country with minimum control from legislative branch. Furthermore, the constitution of 1945 also encouraged the dominant control of central government over the local governments for administrative affairs only. On this occasion, the position of local government merely looks like an extension of central without the delegation of political affairs. This political setting has generated a significant barrier to injecting the democratic values within public institutions, as demanded by society. Therefore, in mid -1998 the chaotic situation occurred between the central government with their military support and the civil society and many supporting organizations carrying their pressure.

At least, the demands from society for a more democratic government can be illustrated in four concrete agendas, comprised of: first, changing Suharto's cabinet with its authoritarian officials, who have proven their failure to counter the economic crisis; second, encouraging the protection of human rights as the pioneering strategy to establish democratic culture; third, abolishing military domination for their political function within governments and banishing their existence within political parties; and fourth, realizing the liberalization of the political party system. All of these demands would be the major reason to conduct an amendment of the highest constitution of 1945.

The series of chaotic demonstrations in 1997-1998 have successfully reached the commitment between the government's agreement and society's demands by realizing the amendment of the highest constitution of 1945 . The downfall of Suharto's regime also became another grant associated with this situation. Basically the amendment of the highest constitution has been conducted in four different periods: October 1999, August 2000, November 2001, and August 2002. This resulted in several prominent changes enabling the injection of democratic souls within public institutions. It also affected the institutional arrangements including the establishment of an independent law enforcement institution. The following (Table 3) describes the specific changes within the configuration of the highest constitution of 1945 during its amendment. 
Table 3

Illustration of amendment of highest constitution 1945

\begin{tabular}{|c|c|c|c|c|c|}
\hline \multirow{2}{*}{$\begin{array}{l}\text { The } \\
\text { amendment } \\
\text { series }\end{array}$} & \multirow[b]{2}{*}{ Year } & \multicolumn{4}{|c|}{ Coverage Areas } \\
\hline & & $\begin{array}{c}\text { Political } \\
\text { Configuration }\end{array}$ & $\begin{array}{c}\text { Economic } \\
\text { Configuration }\end{array}$ & $\begin{array}{l}\text { Administrative } \\
\text { Configuration }\end{array}$ & $\begin{array}{l}\text { Social \& Justice } \\
\text { Configuration }\end{array}$ \\
\hline $\begin{array}{l}\text { First } \\
\text { amendment }\end{array}$ & 1999 & $\begin{array}{l}\text { 1. Placing the } \\
\text { constitution of } 1945 \\
\text { as the highest legal } \\
\text { basis over all public } \\
\text { sector institutions } \\
\text { in Indonesia; } \\
\text { 2. Bordering } \\
\text { the authority } \\
\text { of the president; } \\
\text { 3. Strengthening } \\
\text { the role of legislative } \\
\text { and judiciary } \\
\text { institutions as controller; } \\
\text { 4. Creating the limit } \\
\text { on the period for } \\
\text { the president's tenure }\end{array}$ & & $\begin{array}{l}\text { 1. Amending } \\
\text { rather than } \\
\text { renewing the } \\
\text { highest } \\
\text { constitution; } \\
\text { 2. Enabling the } \\
\text { decentralization } \\
\text { system } \\
\text { (Administratively) }\end{array}$ & $\begin{array}{l}\text { 1. Strengthening } \\
\text { the rule of law } \\
\text { for human rights }\end{array}$ \\
\hline $\begin{array}{l}\text { Second } \\
\text { amendment }\end{array}$ & 2000 & $\begin{array}{l}\text { 1. Settlement for house } \\
\text { of representative } \\
\text { configuration; } \\
\text { 2. Abolishing military } \\
\text { participation } \\
\text { within house } \\
\text { of representative }\end{array}$ & & $\begin{array}{l}\text { 1. Settlement for } \\
\text { the administrative } \\
\text { component } \\
\text { of decentralization } \\
\text { for local } \\
\text { government }\end{array}$ & $\begin{array}{l}\text { 1. Settlement } \\
\text { for the human } \\
\text { right's protection } \\
\text { as equal } \\
\text { to universal } \\
\text { declaration } \\
\text { of human rights }\end{array}$ \\
\hline $\begin{array}{l}\text { Third } \\
\text { amendment }\end{array}$ & 2001 & $\begin{array}{l}\text { 1. Settling the } \\
\text { impeachment's } \\
\text { procedure for president } \\
\text { and vice president; } \\
\text { 2. Establishing the } \\
\text { regional representative } \\
\text { council }\end{array}$ & $\begin{array}{l}\text { 1. Reforming } \\
\text { the Supreme } \\
\text { audit agency }\end{array}$ & & $\begin{array}{l}\text { 1. Encouraging } \\
\text { the participation } \\
\text { of society for } \\
\text { democracy; } \\
\text { 2. Conducting } \\
\text { the direct } \\
\text { presidential and } \\
\text { vice-president } \\
\text { election }\end{array}$ \\
\hline $\begin{array}{l}\text { Fourth } \\
\text { amendment }\end{array}$ & 2002 & & $\begin{array}{l}\text { 1. Settlement } \\
\text { regulation } \\
\text { about economic } \\
\text { and welfare } \\
\text { society; } \\
\text { 2. Settlement } \\
\text { for national } \\
\text { currency and } \\
\text { central bank }\end{array}$ & $\begin{array}{l}\text { 1. Abolishing } \\
\text { the supreme } \\
\text { consultative } \\
\text { agency; } \\
\text { 2. Settlement } \\
\text { of additional } \\
\text { regulation }\end{array}$ & $\begin{array}{l}\text { 1. Independency's } \\
\text { of judicial court; } \\
\text { 2. Culture } \\
\text { and education } \\
\text { for society }\end{array}$ \\
\hline
\end{tabular}

Source: Compiled by the authors.

Table 3 explains that the amendment of the highest constitution of 1945 contains several changes intended to accommodate the demand from society toward the establishment of a more democratic government. Overall, the changes within these amendments cover four major aspects including political, economic, ad- 
ministrative and social configuration. According to Table 1, the first amendment of the highest constitution in 1945 has been intended to set the political commitment to enabling appropriate settlement for the rest of the configurations. This can be seen from the fundamental idea to change the highest authority from the president as part of a representative assembly toward the constitution 1945 itself being the highest legal basis. This shift is intended to prevent the absolute position of president which may lead to an authoritarian government.

\section{Current Progress and Future Challenge}

Either the president's decree number 81 in 2010 or Permenpan number 11 in 2015 have managed the administrative reform in strategic government institutions such as ministerial institutions and provincial governments, as well as local government in either a city or regency. Both of these laws also encourage periodical assessment to measure the progress and identify the challenges faced by those strategic institutions. The current progress of administrative reform's assessment (in 2018) has stated that ministerial institutions and provincial government performed better than local government at city and regency levels. This illustration is described in Table 4, which illustrates the target and realization, as well as the percentage realized.

Table 4

Administrative reform in Indonesia, \%

\begin{tabular}{|l|c|c|c|}
\hline \multicolumn{1}{|c|}{ Institution/ Organization } & Target & Realization & Percentage \\
\hline Ministerial Institution & 100 & 92 & 92 \\
\hline Provincial Government & 100 & 85 & 85 \\
\hline Local Government (City and Regency) & 75 & 46 & 61 \\
\hline
\end{tabular}

Source: Ministry of Administrative and Bureaucratic Reform of Indonesia (2018).

Based on the data presented in Table 5, it can be inferred that on average the achievement of administrative reform performed by public institutions in Indonesia still failed to reach the target set on its roadmap. However, these failures provide a significant lesson for the head of those institutions to evaluate their weakness within their performance. Furthermore, this evaluation process will assist them to identify their future challenges and opportunities to maximize their performance.

The reason behind the failure to reach the target is different for each institution. At ministerial level, it can be seen that the average progress of administrative reform has covered more than $90 \%$ from the overall target of $100 \%$. The reason behind this data is that in Jokowi's cabinet there are frequent ministerial reshuffles which have brought inconsistency to the ministerial program. Jokowi's cabinet also brings the new political trend that is focused on infrastructure development, and some ministerial institutions were less prioritized under these circumstances. However, there is no doubt that the reshuffling process 
initiated by Jokowi has also successfully brought multiple qualified candidates to fill the ministerial positions. Thus, it also contributes a significant impact toward the overall performance.

Then, at the provincial level, the position of leader of the province is filled by the governor who is elected directly through a local election. The overall achievement of the provincial government covers $85 \%$ from the target of $100 \%$. This value is rather less than at the ministerial level. The position of governor enables them to be a double agent; on the one hand they are the leader of the province, but on the other hand they also become the representative of the central government. On this occasion, the policy and program delivered by the provincial government is not as independent at city and regency level because the provincial government has no specific local autonomy.

Finally, at city and regency level, the local mayor accomplished the lowest realization which is $46 \%$ from the overall target of $75 \%$. The target set for city and regency is rather lower than other institutions such as those at ministerial or provincial level because they have different authority. Unlike the ministerial and provincial government, the city and regency have their own local autonomy as regulated through law number 32 of 2004 . Therefore, when compared to ministerial and provincial governments, they tend to be more independent in terms of policy and programs. In some regions, this local autonomy has successfully generated innovative ideas of policy, program, or regulation. However, the rest also face tremendous challenges including the minimum capacity of human resources, lack of innovative ideas for policy formulation, or limited supporting resources. This challenge should be accomplished before they can maximize their performance.

\section{The dilemma of reforms (1998-2010)}

Perhaps 'dilemma' is an appropriate word to illustrate the administrative reform of Indonesia in 1998. It seems no exaggeration to be using this word to describe the reform that was conducted under the critical situations where there was no political, economic, and social stability. The theoretical assumption conveyed by OECD (2001) has proven its relevance to illustrate administrative reform in Indonesia, especially when it has shown its function as a response toward a critical situation instead of anticipation of needs. Under this circumstance, the decision making process in central government has been motorized by multiple stakeholders carrying various demands representing their community (Hermawan, 2014; Kusumasari, Pramusinto, Santoso \& Fathin, 2019).

The fall of Suharto's regime has been replaced with Bacharuddin Jusuf Habibie, otherwise known as President Habibie, as successor to continue the pace of reformists. However, the trend of reform in Indonesia slightly separated from the common reform trends in many developing countries in the 1990s. While other developing countries were strengthening their military involvement within government institutions and following the market-based philosophy (Farazmand, 2002), Indonesia was abolishing military interference within governmental bodies. The fourth amendment of the highest constitution even banished military participation within local elections (reference). 
Taking a more detailed look, the Indonesian reform seems to run without a clear trajectory. The cabinet of president Habibie were reluctant to follow the marketbased philosophy as part of their reform since the main concern was surviving from the crisis impact. Furthermore, the reform has mainly talked about institutional, capacity building, and other mechanisms of re-organization in the public sector rather than privatization or deregulation. Although President Habibie was in position for less than two years, during his tenure there were some prominent policy decisions intended to increase the future government's performance.

Meanwhile, in Abdurrachman Wahid's tenure the reform policy underwent tremendous change in central government, especially in ministerial institutions, with a massive replacement of ministers. This decision caused significant conflict among political parties until the end of his tenure. In Megawati's tenure, however, the trend of reformation shifted into the local level, unlike Habibie's tenure, which was aimed at crisis recovery, or Wahid's tenure, which focused on reform at central government level. Megawati prioritized her attention to local government and she considered giving local autonomy to leaders at city and regency level as an appropriate decentralization principle. The next president after Megawati, Soesilo Bambang Yudhoyono, attempted to carry all the spirit of his predecessors to conduct the administrative reform in central government, local government at city and regency level, as well as local government at the provincial level.

All of these experiences were different from most of the benchmarking countries in Asia, such as South Korea which had a strong reform institution at the beginning of its reform (Berman, Moon \& Choi, 2010). They were also different from China's experience which emphasized military domination at a first glance (Noughton, 2009). Therefore the Indonesian administrative reform was merely the result of various agendas of political leaders' who attempted their best to reach the maximum performance of government without a clear vision for long term orientation. In some perspectives, this condition is also relevant to the reform fatigue as referred by OECD (2001), especially when the succeeding leaders tended to bring new reform ideas rather than continuing the long term plan of their predecessor.

\section{Rebuild the reform trajectory (2010-2019)}

The existence of trajectory has been recognized as a viable solution to reach the desired outcome under the confusion within administrative reform (Pollitt \& Bouckaert, 2017). Under the reformation case in Indonesia, the focus of administrative reform is not quite clear, especially within the first decade of its implementation. However, in the second term of SBY's tenure, the discussion about long term goals of administrative reform had been a concern (Prasojo, 2012). The seeking of the major focus within the reformation's pace was also analyzed through a set of experiences from the previous leaders. At the end of his tenure, SBY signed the president's decree number 81 configuring long term goals of administrative reform, known as the grand design of administrative reform.

In the most fundamental review, the grand design of Indonesian administrative reform provides a viable track for all public institutions in Indonesia to achieve integrated action for their best administrative performance. This trajectory reflects 
the sustainability of the target between the short, middle and long terms in most public institutions in Indonesia. It is also equipped with the administrative reform roadmap ensuring the role of trajectory and mileage in a clear measurement. The creation of this trajectory is inherited from the past experience of previous leaders, carrying various priorities of administrative reform components. It covers some prominent aspects as the main consideration, comprising accountability, effectivity and efficiency within public service delivery.

In theoretical aspects, the essence of this grand design is in minimizing the space of political streamline within the administrative reform itself (Bidya \& Ora, 2014). An example illustrating this fact is when the administrative reform is always interfered with by the political disposition of the national leader's decision, the result being that every change of national leadership has always seen the emergence of a new reform agenda that is unconnected with the past (Prasojo, 2012). The existence of this trajectory ensures the reversal of any political decisions of a leader that are unrelated to the fixed purposes of administrative reform written in the grand design. Consequently, every program reform policy and program will always be consistent with his predecessor (Pollitt \& Bouckaert, 2004). Although it seems that the existence of a trajectory provides a fixed border for the political aspect to make a further agenda, it is impossible to completely separate the political aspect within the administrative process. This means that the existence of political support within administrative reform is absolutely necessary in order to ensure it is a comprehensive process within a dynamic bureaucratic environment.

While in practice, the trajectory of administrative reform has been designed to create an integration among political support, human resource personnel, budgeting and current trends in administrative reform, it has cultivated a reform mechanism that is applicable to be implemented in ministerial and local government either at the province or city level. The results of these institutions reflect the different performance of leaders; on the one hand they are appointed by the president but on the other hand they are elected through local elections. These facts reflect the relationship between bureaucratic and political performance within the reform process.

\section{The synchronization and future projection (2020-2024)}

Although the ideas of administrative reform noted in the grand design (President's decree 81/2010) and road map (Permenpan 11/2015) cover the long term goals, it is sometimes seen as a too ambitious pathway. The main vision of administrative reform in Indonesia is 'terwujudnya pemerintahan kelas dunia' which means to realize world class governance. Perhaps, this vision is often appropriate to be a main goal for ministerial institutions that are coordinated by central government. However, some government leaders at the province and city level might find themselves to be a burden together with this vision (Tab. 5).

Indeed, it has been acknowledged that the existence of structure within bureaucracy will always cultivate its own administrative culture (Kallinikos, 2006). Regarding this statement, both the grand design (President's decree 81/2010) and its road map (Permenpan 11/2015) have been considered as a contrast to replace the old 
structure of bureaucracy in some local institutions. Thus, the process to cultivate a new administrative culture is hindered by strong resistance against the trajectory. While, theoretically, successful reform is often associated with an applicable structure within the trajectory itself (Pollitt \& Bouckaert, 2004;), even this reform was initiated by bottom up approaches without specific long term purposes at beginning (Killian \& Eklund, 2008). Thus the ministry of administrative reform should make it a priority to synchronize this matter within the relevant situation at the local level.

The next aspect that needs to be synchronized is the leadership aspect as one of the important factors determining the success of administrative reform (Farazmand, 2004). Within this research, the finding illustrates a lack of performance in maintaining the administrative reform at the local level rather than that at the ministerial level. This finding illustrates a minister with administrative authority achieving better performance than the leader at the local level with their political authority. In the future, it will be a significant challenge to formulate a suitable trajectory with comprehensive attributes suitable for all the characteristics of public institutions in Indonesia. Either from a general trajectory or leadership aspect, various characteristics of public institutions will be required to find their cohesion in order to minimize asymmetric between reform policy and its downstream implementation.

\section{Conclusion}

According to the series of discussions presented in previous sections, it can be inferred that the administrative reform in Indonesia has undergone some transformative periods since its first declaration in 1998. In the early years of its progress, the focus of reform was blurred by unstable conditions, especially in the political and economic environment. Under these circumstances, the core of reform seems difficult to recognize because many Indonesian leaders were still focusing on political and economic recovery. However, in late 2010, the president, SBY, was setting the reform grand design as the main trajectory of administrative reform for all public institutions in Indonesia. This paper has recognized this period as a turning point from the reform stagnation of the previous age. Following the same path, the current progress of administrative reform resulted in a comparable value among the three dominant public institutions in Indonesia, comprised of ministerial institutions, provincial governments, and local governments at the city and regency levels. The current assessment from these institutions has resulted in a higher value in centralized institutions such as ministerial and provincial institutions. While in decentralized institutions at the local level the value tends to be lower than the previous one.

\section{Acknowledgement}

We would like to thank Tommy Anggriawan who contributed to our manuscript. We also would like to thank the editorial team and reviewer for their comments and suggestions. 


\section{REFERENCES}

1. Alam, M.S. \& Khair, R. (2006). Administrative Reform in South and Southeast Asia: Trends Lesson and Challenges. Public Administration Training Centre of Bangladesh. Bangladesh.

2. Allen, F. \& Gale, D. (2002). The Asian Crisis and The Process of Financial Contagion. University of Pennsylvania. USA. Available at: http://finance.wharton.upenn.edu/ allenf/download/ Vita/theasian.pdf (accessed: 18 December 2020).

3. Alm, J., Vazquez, J.M. \& Indarwati, S.M. (2004). Reforming Intergovernmental Fiscal Relations and The Rebuilding of Indonesia: The 'Big Bang' Program and its Economic Consequences. Edward Elgar Publishing. UK.

4. Anggriawan, T. (2016). The Sub-Regional Cooperation's Role in Assisting the Implementation of ASEAN Economic Community Blueprint to Develop the Small Medium Enterprise: Case Study in Indonesia, Malaysia, Thailand-Growth Triangle (IMT-GT). University of Brawijaya. Thesis.

5. Banks, G. (2005). Structural Reform Australian-Style: Lesson for Others?. Official document for Presentation to the IMF, World Bank, and OECD 2005. Australian Government. Available at: https://www.pc.gov.au/news-media/speeches/cs20050601/cs20050601.pdf (accessed: 11 August 2019).

6. Benouareth, Ch. \& Gacem, M. (2019). Understanding 'Joining-up-Government' Reforms in the Anglo-Saxon Nations from a Cultural Point of View. Public Administration Issues, Special Issue I (electronic edition), pp. 27-45. Available at: DOI: 10.17323/1999-5431-2019-0-5-27-45 (accessed: 11 August 2019).

7. Berman, E.M., Moon, M.J. \& Choi, H. (2010). Public Administration in East Asia: Mainland China, Japan, South Korea, and Taiwan. CRC Press, London.

8. Bidya, B. \& Ora, P. (2014). Bureaucratic Politics and Administrative Reform: Why Politics Matters. Chiang Mai University, Thailand. Available at: DOI: 10.1007/s11115-010-0129-0 (accessed: 18 December 2019).

9. Breuker J., Valente A. \& Winkels R. (2005). Use and Reuse of Legal Ontologies in Knowledge Engineering and Information Management. In: Benjamins V.R., Casanovas P., Breuker J., Gangemi A. (eds) Law and the Semantic Web. Lecture Notes in Computer Science, vol. 3369. Springer, Berlin, Heidelberg. Available at: https://doi.org/10.1007/978-3-540-32253-5_4 (accessed: 18 December 2020).

10. Caiden, G.E. (1991). Administrative Reform. Chicago: Aldine/Atherton.

11. Caiden, G.E. (1988). The Vitality of Administrative Reform. International Review of Administrative Sciences, vol. 54, no 3, pp. 331-357.

12. Caiden, G.E. 1991. Administrative Reform Comes of Ages. New York: W. de Gruyter.

13. Chester, D.W. \& Wilson, F.M.G. (1968). The Organization of British Central Government, 1914-1964. 2nd ed. London: Allen and Unwin.

14. Cheung, A. B. L. (2005). The Politics of Administrative Reforms in Asia: Paradigms and Legacies, Paths and Diversities. Governance: An International Journal of Policy, Administration, and Institutions, vol. 18, no 2, pp. 257-282. Blackwell Publishing.

15. Cope, G.H. (1997). Bureaucratic Reform and Issues of Political Responsiveness. Journal of Public Administration Research and Theory, J-Part, vol. 7, no 3, pp. 461-471. 
16. Demir, I. \& Aktan, C.C. (2016). Resistant to Change in Government: Actors and Factors that Hinder Reform in Government. International Journal of Social Sciences and Humanity Studies, vol. 8, no 2, ISSN 1309-8063 (Online).

17. Farazmand, A. (2002). Administrative Reform in Developing Nations. London. Preager Publisher.

18. Farazmand, A. (1999a). Administrative Reform in Global Perspective: A Symposium. International Journal of Public Administration, vol. 22, no 4, pp. 1-9.

19. Farazmand, A. (1998b). Globalization and Public Administration. Public Administration Review, vol. 57, no 6, pp. 509-522.

20. Fischer, F., Miller, G.J. \& Sidney, M.S. (2007). Handbook of Public Policy Analysis: Theory, Politics, and Methods. CRC Press.

21. Fullan, M.G. (1994). Coordinating Top-Down and Bottom-Up Strategies for Educational Reform: Perspectives on Personalizing Education. Available at: http://michaelfullan.ca/wp-content/ uploads/2016/06/13396035630.pdf (accessed: 24 March 2019).

22. Guga, E. (2018). Local Government Modernization in Albania. International Journal of Public Sector Management, vol. 31, no 4, pp. 466-506.

23. Haferkamp, H. \& Smelser, N.J. (1992). Social Change and Modernity. University of California Press.

24. Hermawan, R. (2014). Coordination and Civil Service Reform in Indonesia (1999-2009). Center of South South Cooperation Studies. University of Brawijaya.

25. Islam, S.N. (2016). Governance for Development: Political and Administrative Reforms in Bangladesh. Palgrave Macmillan. ISBN: 978-1-349-71292-2.

26. Jeon, B.N. (2012). From the 1997-98 Asian Financial Crisis to the 2008-09 Global Economic Crisis: Lesson from Korea's Experience. MPRA's Paper No. 36469. Available at: https://mpra. ub.uni-muenchen.de/36469/ (accessed: 18 December 2020).

27. Jorgensen, T.B. (2006). Changing European States, Changing Public Administration: From Continental Law to Anglo-Saxon Behaviorism: Scandanavian Public Administration. In: Eric E. Otenyo, Nancy S. Lind (ed.) Comparative Public Administration (Research in Public Policy Analysis and Management, Volume 15) Emerald Group Publishing Limited, pp. 811-830.

28. Killian, J. \& Eklund, N. (2008). Handbook of Administrative Reform: An International Perspective. CRC Press.

29. Kuhlmann, S. (2015). Administrative Reform in Context: A Comparative Perspective. University of Potsdam. Available at: https://www.uni-potsdam.de/fileadmin01/projects/ls-kuhlmann/ Starseite/Neuigkeiten/Adm-Ref-sk.pdf (accessed: 9 February 2019).

30. Khemani, S. (2017). Political Economy of Reform. Policy Research Working Paper 9224. World Bank Group.

31. King, D.Y. (2003). Half-Hearted Reform: Electoral Institutions and Struggle for Democracy in Indonesia. Greenwood Publishing. Available at: DOI: 10.1017/S1537592704770693 (accessed: 18 December 2020).

32. Kisner, M. \& Vigoda-Gadot, E. (2017). "The provenance of public management and its future: is public management here to stay?”, International Journal of Public Sector Management, vol. 30, no 6-7, pp. 532-546. 
33. Kusumasari, B., Pramusinto, A., Santoso, A.D. \& Fathin, C.A. (2019). What Shapes Public Sector Innovation? Public Policy and Administration, vol. 18, no 4, pp. 43-446.

34. Lane, J.E. (1997). Public Sector Reform: Rationale, Trends, and Problems. Sage Publication.

35. Maggy, et al. (2012). Transforming the Public Sector in Indonesia: Delivering Total 'Reformasi'. World Bank Working Group.

36. Mietzner, M. (2006). The Politics in Post-Suharto Indonesia: Elite Conflict, Nationalism, and Institutional Resistance. East-West Center Washington. United States.

37. Miller, M.A. (2009). Rebellion and Reform in Indonesia: Jakarta Security and Autonomy Policies in Aceh. Routledge. London.

38. Meer, F.V.D. (2009). Public Sector Reform in Western Europe and The Rise of The Enabling State: An Approach to Analysis. University of Leiden. Available at: DOI: 10.13140/2.1.1628.3520. Url: https://www.researchgate.net/publication/265092766 (accessed: 18 December 2020).

39. Naughton, B. (2009). China: Economic Transformation Before and After 1989. Conference paper '1989: Twenty Years After'. University of California, Irvine. United States.

40. Nikos, M. (2002). Trends of Administrative Reform in Europe: Toward Administrative Reform Convergence. International Public Management Review, vol. 2, no 2.

41. Ocampo, R.B. (2002). Models of Public Administration Reform: New Public Management (NPM). Asian Review of Public Administration. Available at: https://pdfs.semanticscholar.org/ 5911/578cdc5227d1a9cb9ce88289aec50fe9f99c.pdf (accessed: 7 May 2019).

42. OECD. (2001). Government of the Future: Governance. Organization for Economic Co-operation and Development Publication, Paris. France.

43. Ohemeng, F. (2010). The Dangers of Internationalization and "One-Size-Fits-All" in Public Sector Management. International Journal of Public Sector Management, vol. 23, no 5, pp. 456-478.

44. Ooghe, H. \& Langhe, T.D. (2002). The Anglo-American versus the Continental European corporate Governance Model: Empirical Evidence of Board Composition in Belgium. Journal of European Business Review, vol. 14, no 6, pp. 437-449.

45. Ortiz, G. (2003). Latin America: Overcoming Reform Fatigue. Available at: https://pdfs.seman ticscholar.org/3bff/5f21aa2ec100c96fad037000289a2c3929bd.pdf (accessed: 11 August 2019).

46. Peters, G. (1994). Government Reorganization: A Theoretical Analysis." In: Ali Farazmand (ed.) Modern Organizations: Administrative Theory in Contemporary Society. Westport, CT: Praeger.

47. Pollitt, C. \& Bouckaert, G. (2004). Public Management Reform: A Comparative Analysis $2^{\text {nd }}$ Edition. Oxford: Oxford University Press.

48. Pollitt, C. \& Bouckaert, G. (2017). Public Management Reform: A Comparative Analysis $4^{\text {th }}$ Edition 'into the Age of Austerity'. Oxford: Oxford University Press.

49. Prasojo, E. (2012). Indonesian Bureaucratic Reform in the Making. A note from deputy of Administrative Reform minister of Indonesia. The Jakarta Post Publication, edition 8 March 2012.

50. Proni, M.W. (2012). An Economic Analysis of Unemployment in Brazil. Global Labour University. Available at: https://www.global-labour-university.org/fileadmin/GLU_conference_2010/ papers/65._An_Economic_Analysis_of_Unemployment_in_Brazil.pdf (accessed: 18 December 2020). 
51. Roy, A. (2016). The Causes of Underdeveloped in the Third World and Possibility for Human Development. Available at: https://www.researchgate.net/publication/307138568 (accessed: 18 December 2020).

52. Sarker, A.E. (2006). New Public Management in Developing Countries. International Journal of Public Sector Management, vol. 19, no 2, pp. 180-203.

53. Schick, A. (2002). Agencies in Search of Principles. OECD Journal on Budgeting, vol. 2, no 1, pp. 7-26.

54. Siddiquee, N.A \& Xavier, J.A. (2020). Collaborative Approach to Public Service Improvement: the Malaysian Experience and Lessons. International Journal of Public Sector Management. Available at: DOI 10.1108/IJPSM-05-2020-0122 (accessed: 18 December 2020).

55. Smalskys, V. (2002). Kontinentines Europos viešojo administravimo geneze [Genesis of Public Administration in Continental Europe] (Translated from Lithuanian). Public Policy and Administration Research Journal, vol. 1, no 1.

56. Strehlenert, H. (2017). From Policy to Practice: Exploring the Implementation of a National Policy for Improving Health and Social Care. PhD Dissertation. Karolinska Institut. Sweden.

57. Thoha, M. (2000). [The Administrative Reform in Post of New Order Era: A Reform with No Grand Design] (Reformasi Birokrasi Publik Pasca Orde Baru: Perubahan Tanpa Grand Design). Jurnal Ilmu Sosial \& Politik, vol. 4, no 1, 2000. ISSN 1410-4946.

58. Volger, J.P. (2018). The Political Economy of Public Bureaucracy: The Emergence of Modern Administrative Organizations. Working Paper of Duke University. Available at: http://www. janvogler.net/PE_of_Bureaucracy.pdf (accessed: 30 July 2019).

59. Vries, M.S. (2016). Reform Fatigue: The Effect of Reorganizations on Public Sector Employees. Radboud University of Nijmegen. Netherland. Available at: http://www.nispa.org/files/ conferences/speeches/201304191553120.nispa\%202013\%20De\%20Vries\%20Reform _ fatigue.pdf (accessed: 11 August 2019).

60. Wagner, P. (2001). A History and Theory of the Social Sciences, London: Sage.

61. Warin, T. (2005). A Note on the Anglo-Saxon and Continental Approaches to Europe: Identical in Spirit, not in Practice. Middleburg College Economics. Discussion Paper. Available at: http://citeseerx.ist.psu.edu/viewdoc/download?doi=10.1.1.834.7405\&rep=rep1\&type=pdf (accessed: 02 April 2019).

\section{OFFICIAL DOCUMENTS}

1. The Regulation of the Ministry of Administrative and Bureaucratic Reform of Indonesia No. 30 of 2018 on Guidelines for Evaluation of Administrative Reform in Government Institution.

2. The President's Decree of Indonesia No. 81 of 2019 on Grand Design of Bureaucratic and Administrative Reform of Indonesia. 